\title{
CORRECTION OF PES PLANOVALGUS IN CEREBRAL PALSY: A SHORT TERM OUTCOME OF EXTRA-ARTICULAR SUBTALAR ARTHRODESIS
}

\author{
Tarek Hassan Abdelaziz, Mohamed Nabil Al Sayed, Amr Farouk Mohamed, \\ Ahmed Said Ali MD, Mohamed Nabil Mahmoud M.Sc*
}

Orthopaedic Department, Faculty of medicine, Ain Shams University. And * Orthopedic Specialist, Ministry of Health/ International Medical Center Corresponding Author: Mohamed Nabil Mahmoud Phone No.: (+201005152199

E-mail:

nabilortho7716@gmail.com, Received: $12 / 4 / 2020$

Accepted: $4 / 5 / 2020$

Online ISSN: 2735-3540

\section{ABSTRACT:}

Background: Pes planovalgus is the most common foot deformity observed in cerebral palsy (CP) patients causing pain, gait abnormality, instability and in severe deformity. It can lead to brace intolerance. The treatment of this deformity should be directed to correct the foot malalignment, secure the stability of the foot during stance and correct the abnormal gait. After failure of conservative treatment, surgical treatment is the option. It varies from simple soft tissue procedures to tarsal osteotomies, subtalar extra-articular arthrodesis, intra-articular arthrodesis and triple arthrodesis. When these are compared, all techniques have advantages and disadvantages.

Aim of the Work: This prospective clinical study is conducted to evaluate the short term outcome of the extra-articular subtalar arthrodesis using fibular graft that harvested from the junction between the proximal 1/3 and the distal 2/3 of the fibula in correction of flexible pes planovalgus in children with cerebral palsy.

Patients and methods: We conducted a prospective study involving 13 patients (22 feet) with cerebral palsy who failed conservative treatment for more than 6 months. Postoperative complications were recorded. Assessment of the patients clinically and radiologically was done and compared to that of the preoperative data.

Results: Clinical results were satisfactory in 21 feet and unsatisfactory in 1 foot according to kim et al scoring system. Radiologically; the anteroposterior talocalcaneal angle decreased from the median of $26^{\circ}$ (range $11^{\circ}-56{ }^{\circ}$ preoperative to $9.5^{\circ}$ (range $1^{\circ}-35^{\circ}$ post operative. The lateral talocalcaneal angle deceased from the mean of $42.05^{\circ} \pm 7.35^{\circ}$ preoperative to $28.73^{\circ} \pm 8.51^{\circ}$ postoperative. The anteroposterior talus-first metatarsal angle decrease from the median of $24^{\circ}$ (range $3^{\circ}-559$ preoperative to $8^{\circ}$ (range $1^{\circ}-39^{\circ}$ ) postoperative. The lateraltalus-first metatarsal angle decreased from the median of $20^{\circ}$ (range $3^{\circ}-479$ preoperative to $8.5^{\circ}$ (range $0^{\circ}-189$ postoperative and the calcaneal pitch angle increased from the median of $5^{\circ}$ (range $-19^{\circ}-229$ preoperative to $10^{\circ}$ (range $2^{\circ}-17^{\circ}$ ) postoperative. The postoperative changes were statistically highly significant.

Conclusion: The extra-articular subtalar arthrodesis in our study as in others had been proved to be effective, safe, simple and non expensive procedure for correction of flexible pes planovalgus feet in children with cerebral palsy. 
Key words: Extra-articular subtalar arthrodesis, Grice Green procedure, valgus feet, foot deformities correction, cerebral palsy.

\section{INTRODUCTION:}

Pes planovalgus is the most common foot deformity observed in cerebral palsy (CP) patients whichis characterized by a loss of the medial longitudinal arch and malalignment of the foot that consistsof plantar flexion and valgus of the hind foot, and abduction and supination of the forefoot ${ }^{(1)}$. Muscle imbalance, spasticity and tightness of the calf and peroneal muscles are the main causes ${ }^{(2)}$.

Pain, gait abnormality, instability and in severe deformity it can lead to brace intolerance secondary to pressure medially over the prominent talar head which make it a clinical problem. ${ }^{(1)}$. Flexible planovalgus foot deformities are classified into two groups according to their severity as follows. The mild to moderate group in whom the hindfoot valgus is flexible enough to be corrected to normal and the severe group in whom hindfoot valgus can not be corrected to normal ${ }^{(3,4,5)}$.

The treatment of this deformity should correct the foot malalignment, secure the stability of the foot during stance, and correct the abnormal gait ${ }^{(1)}$.

The aim of the treatment is to obtain a foot with normal alignment which exhibits no pain, secure the stability of the foot during stance, correct the abnormal gait, and prevent the degenerative changes that may take place in the future. Initially, conservative treatment must be tried. However, with growth,the progression of the deformity can not be stopped by conservative measures because of the persisting muscle spasticity. Prior to development of permanent contractures and structural osseous changes, surgical options should be offered to the patient ${ }^{(6)}$.
Clinical evaluation should include family history, associated medical conditions, presence or absence of symptoms, trauma history, activity level, previous treatment, and a thorough review of other systems. Obesity, neuromuscular disorders, and structural abnormalities above the level of the ankle (e.g., ankle valgus, tibia varum, genu valgum, tibial torsion, femoral anteversion, limb-length discrepancy) can influence both the natural history and the severity of pediatric flatfoot $^{(7)}$.

Radiological assessment consists of five parameters in accordance with angular measurements that are directly associated with the deformity. These angles are:Anteroposterior talus-first metatarsal (range from $0^{\circ}$ to $5^{\circ}$ ), and lateral talus-first metatarsal (Meary's angle range $0^{\circ}$ to $10^{\circ}$ ) measures cavus/planus foot, and calcaneal pitch angles (normal range $20^{\circ}-25^{\circ}$ ) evaluate the hindfoot plantar flexion (8). Anteroposterior talocalcaneal angle (Kite angle; normal range: $15^{\circ}-55^{\circ}$ ) and lateral talocalcaneal angle TCL (normal range: $25^{\circ}$ $55^{\circ}$ ) evaluate subtalar varus/ valgus of subtalar joint ${ }^{(6)}$. Ankle valgus is also assessed as described by Malhotra et al. ${ }^{(2,8,9)}$.

After failure of conservative treatment, surgical treatment is the option. It varies from simple soft tissue procedures to tarsal osteotomies, subtalar extra-articular arthrodesis, intra-articular arthrodesis and triple arthrodesis. When these are compared, all techniques have advantages and disadvantages $^{(10)}$.

\section{AIM OF THE WORK:}

The aim of this study is to assess the short term outcome of extra-articular 
subtalar arthrodesis for correction of pes planovalgus in CP patients.

\section{PATIENTS AND METHODS :}

- $\quad$ Study design: prospective clinical study.

- Setting: Ain Shams University Hospitals between August 2016 and December 2019.

After obtaining the hospitals Research/ Ethics Committee approval and written informed consents from the patients, this study was carried on thirteen patients with cerebral palsy (22 feet), table (1) with flexible pes planovalgus at Ain Shams University Hospitals.

All patients were screened for eligibility by detailed clinical assessment of their history and physical examination as well as investigations required and those who met the inclusion criteria were included in this study.

Table 1: Patients’ demographic data

\begin{tabular}{|l|c|c|}
\hline \multirow{2}{*}{ Age in years } & & No. $=22$ \\
\cline { 2 - 3 } & Mean \pm SD & $9.00 \pm 3.64$ \\
\hline \multirow{3}{*}{ Gender } & Range & $5.25-19$ \\
\cline { 2 - 3 } & Female & $8(61.5 \%)$ \\
\hline \multirow{3}{*}{ Gide } & Male & $5(38.5 \%)$ \\
\cline { 2 - 3 } & Right & $2(15.4 \%)$ \\
\cline { 2 - 3 } & Left & $2(15.4 \%)$ \\
\hline \multirow{3}{*}{ Associated tight TA } & Bilateral & $9(69.2 \%)$ \\
\cline { 2 - 3 } & 2 & $13(59.1 \%)$ \\
\cline { 2 - 3 } & 3 & $7(31.8 \%)$ \\
\hline \multirow{2}{*}{ Bilateral } & 4 & $2(9.1 \%)$ \\
\cline { 2 - 3 } & No & $20(90.9 \%)$ \\
\hline Previous operation for LL deformity & Yes & $2(9.1 \%)$ \\
\cline { 2 - 3 } & No & $4(18.2 \%)$ \\
\cline { 2 - 3 } & Yes & $18(81.8 \%)$ \\
\cline { 2 - 3 } & No & $8(36.4 \%)$ \\
\hline
\end{tabular}

\section{Inclusion criteria:}

1. Ambulatory spastic CP patient up to grade 4 Gross Motor Function Classification System (GMFCS).

2. Symptomatic correctable pes planovalgus (i.e.: full passive correction of hind foot valgus).

3. Skeletally immature patients.

4. Failure of conservative treatment for more than 6 months.

\section{Exclusion criteria:}

1. Non ambulatory children with GMFCS 5.

2. Incorrectable (rigid) hind foot valgus.

3. Skeletally mature patients.
4. Ankle valgus from tibiotalar joint rather than subtalar.

\section{* Patient evaluation:}

\section{Clinical evaluation:}

Detailed history of the onset of the flatfoot, progression of flatfoot, previous operations and other CP deformities. Examination of the ankle \& subtalar mobility, muscle imbalance to estimate the need for additional tendon lengthening procedures, hindfoot position [categorized: 0 - any varus, 1 - normal $\left(0^{\circ}-7^{\circ}\right), 2$ - mild valgus $\left(7^{\circ}-15^{\circ}\right), 3$ - moderate valgus $\left(15^{\circ}\right.$ $25^{\circ}$ ) and 4 - severe valgus $\left(>25^{\circ}\right)$ ] and Gross Motor Function Classification System GMFCS. 


\section{Radiographic evaluation:}

Weight-bearing ankle and foot radiographs (anteroposterior and lateral) were taken. They were evaluated for the AP and lateral talocalcaneal angles, AP and lateral talo-first metatarsal angels, calcaneal pitch angle, graft position and union.

\section{Operative Procedure:}

a. Grice Green extra-articular arthrodesis of the subtalar joint using fibular graft was done with tendo-achillis lengthening done concomitantly if needed.

b. Patients with bilateral affection were operated on simultaneously.

Fibular graft was taken from the junction between proximal $1 / 3$ and distal 2/3 of the fibular shaft with caution to the peroneal nerve and periosteum closure.

\section{Surgical technique:}

Under a tourniquet control, a $5 \mathrm{~cm}$ oblique skin incision centered over the sinus tarsi was applied to the lateral portion of the foot. After passing through the subcutaneous layer, the cutaneous branch of the sural nerve, peroneal tendons, and extensor digitorum brevis were exposed and retracted. The sinus tarsi was visualized and cleaned from the soft tissues. Then, plantar flexion and inversion were applied to the foot. The calcaneus was held inverted out of its valgus position under the talus and dorsiflexion of the foot was attempted. The graft bed was prepared by removing osseous blocks from the undersurface of the talus (roof of the sinus tarsi) and the upper surface of the calcaneus (floor of the sinus tarsi) and the length of the graft to be applied was determined. The ipsilateral fibula was used as the donor for the graft. A 5-6 cm lateral longitudinal incision was applied between the proximal $1 / 3$ and distal $2 / 3$ of the fibula. After passing through the subcutaneous layer, the fascia was incised with great care not to damage the peroneal nerve. Deep dissection was done through the plane between the anterior and the lateral compartment down to the bone. A longitudinal incision in the periosteum was done and a subperiosteal strut graft was obtained from the junction of the proximal $1 / 3$ and the distal $2 / 3$ of the fibula. Fibular osteotomy was carried out using an oscillating saw by respecting the periosteum in each case. The graft was placed into its bed in the sinus tarsi extra-articularly while forcing the subtalar joint into the varus position. Attention was paid to ensure that the long axis of the graft was parallel to the long axis of the tibia while the ankle was held in a neutral position. Stability of the graft and correction of the excess heel valgus were confirmed by applying valgus stress. Fixation of the graft using K-wire from the plantar surface of the calcaneus was done through the fibular graft to the talus. The tourniquet was deflated and hemostasis was ensured. The incisions were closed in a standard manner with subcuticular absorbable sutures.

\section{Postoperative:}

All feet were immobilized in above knee cast with knee flexion for 6 weeks then short leg cast for another 6 weeks. After removal of the cast and the k-wire, the patients used insoles and modified shoes which off-load the medial side of the foot and hence relief the stresses on the graft and support the medial border of the foot in order to maintain the normal foot tripod structure.

\section{Follow up:}

Weight-bearing ankle and foot radiographs (anteroposterior and lateral) were taken preoperatively, immediate postoperative, at 2 weeks, 6 weeks, 3 months and at 6 months then every 6 months. They were evaluated for the AP and lateral talocalcaneal angles, AP and lateral talo-first metatarsal angels, calcaneal pitch angle, graft position and union. The graft was considered healed when trabecular bone 
formation across both talus and calcaneus was evident. Resorption was described by any radiolucency crossing the graft. The clinical outcomes were assessed as satisfactory and unsatisfactory according to the scoring system used by Kim et $\mathrm{al}^{5}$ at the final follow up visit.

\section{RESULTS}

The clinical outcome was assessed as satisfactory and unsatisfactory using the scoring system used by Kim et $\mathrm{al}^{5}$.This scoring system consists of 4 components; improvement of pain or callus, correction of forefoot abduction, formation of a medial longitudinal arch and correction of the hindfoot valgus. The results considered as satisfactory when the total score was 8 or more (Table 2).

Table 2: Scoring system for clinical outcomes by Kim et al. ${ }^{5}$

\begin{tabular}{|l|l|l|l|l|}
\hline Point & Pain/callus & Forefoot Abd. & Longitudinal arch & Hindfoot Valgus \\
\hline 3 & None & Normalized & Normalized & Normalized \\
\hline 2 & Improved & Improved & Improved & Improved \\
\hline 1 & Minimal change & Minimal change & Minimal change & Minimal change \\
\hline 0 & Persistent & No change, overcorrection, recurrence & \\
\hline
\end{tabular}

Satisfactory; 8 to 12 points, unsatisfactory; 0 to 7 points.

Regarding the forefoot abduction correction; 15 feet had no residual deformity and 7 feet were improved. Regarding the hindfoot valgus correction; 18 feet had no residual deformity and 4 feet were improved. Regarding the medial longitudinal arch correction; 2 feet showed minimal change, 15 feet were improved and 5 feet had no residual deformity. There was no residual pain in 13 feet and the pain was improved in 9 feet.

The net results were satisfactory in 21 feet and unsatisfactory in 1 foot according to Kim et al. scoring system.

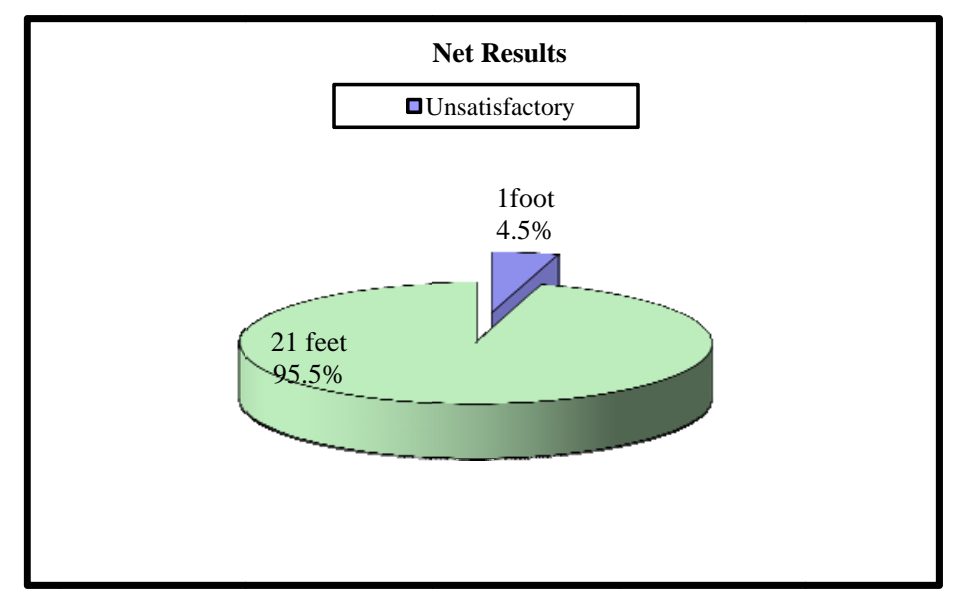

Diagram 1: Pie chart showing the clinical outcome results according to Kim et al. scoring system.

\section{Radiographic parameters:}

All angles improved with high statistical significance (table 3). The AP-TCA decreased from the median of $26^{\circ}$ preoperative to $9.5^{\circ}$ post operative. The lat.TCA deceased from the mean of $42.05^{\circ} \pm$ $7.35^{\circ}$ preoperative to $28.73^{\circ} \pm 8.51^{\circ}$ postoperative. This decrease indicates improvement of the heel valgus. The AP talo- $1^{\text {st }}$ MTS decrease from the median of $24^{\circ}$ preoperative to $8^{\circ}$ postoperative that indicates improvement of the forefoot abduction. The lat. talo- $1^{\text {st }}$ MTS decreased 
from the median of $20^{\circ}$ preoperative to $8.5^{\circ}$ postoperative and the calcaneal pitch angle increased from the median of $5^{\circ}$ preoperative to $10^{\circ}$ postoperative which indicate improvement of the medial longitudinal arch.

Table 3: Preoperative and postoperative radiographic measurements.

\begin{tabular}{|c|c|c|c|c|c|c|}
\hline & Pre & Post & \multirow[t]{2}{*}{ Test value } & \multirow[t]{2}{*}{ P-value } & \multirow[t]{2}{*}{ Sig. } \\
\hline & & No. $=22$ & No. $=22$ & & & \\
\hline \multirow[t]{2}{*}{ AP-TCA } & Median(IQR) & $26(19-37)$ & $9.5(6-15)$ & \multirow[t]{2}{*}{-4.108} & \multirow[t]{2}{*}{0.000} & \multirow[t]{2}{*}{$\mathrm{HS}$} \\
\hline & Range & $11-56$ & $1-35$ & & & \\
\hline \multirow[t]{2}{*}{ Lat. TCA } & Mean \pm SD & $42.05 \pm 7.35$ & $28.73 \pm 8.51$ & \multirow[t]{2}{*}{10.532} & \multirow[t]{2}{*}{0.000} & \multirow[t]{2}{*}{$\mathrm{HS}$} \\
\hline & Range & $26-62$ & $10-44$ & & & \\
\hline \multirow[t]{2}{*}{ AP talo-1st MTS } & Median(IQR) & $24(14-39)$ & $8(6-18)$ & \multirow[t]{2}{*}{-3.914} & \multirow[t]{2}{*}{0.000} & \multirow[t]{2}{*}{$\mathrm{HS}$} \\
\hline & Range & $3-55$ & $1-39$ & & & \\
\hline \multirow[t]{2}{*}{ Lat. Talo-1st MTS } & Median(IQR) & $20(12-33)$ & $8.5(4-10)$ & \multirow[t]{2}{*}{-4.012} & \multirow[t]{2}{*}{0.000} & \multirow[t]{2}{*}{ HS } \\
\hline & Range & $3-47$ & $0-18$ & & & \\
\hline \multirow[t]{2}{*}{ Calcaneal pitch angle } & Median(IQR) & $5(2-8)$ & $10(8-11)$ & \multirow[t]{2}{*}{-3.209} & \multirow[t]{2}{*}{0.000} & \multirow[t]{2}{*}{$\mathrm{HS}$} \\
\hline & Range & $-19-22$ & $2-17$ & & & \\
\hline
\end{tabular}

$\mathrm{P}>$ 0.05: Non significant; $\mathrm{P}<0.05$ : Significant; $\mathrm{P}<0.01$ : Highly significant

\section{Complications:}

Regarding the complications, 7 feet showed no radiological union, two feet had sinus tarsi pain (improved with local steroid injection), one foot was under corrected and one patient had peroneal nerve injury that spontaneously resolved after 3 months. However, no patient developed postoperative infection.

\section{Case Presentation}

7 yrs 6 months aged boy with $\mathrm{CP}$ GMFCS 2 suffered from Lt foot flexible PPV that failed conservative treatment for 6 months prior to surgery. The deformity was mild regarding the forefoot abduction and moderate heel valgus with collapse of the medial arch. No history of previous operations. On examination, there was no associated LL deformity or tight tendoachillis. Clinical outcome: the foot showed good clinical correction with no residual forefoot abduction, heel valgus or medial arch collapse. The patient and parents were satisfied with the results (Score 12) according to Kim et al. scoring system which was satisfactory. There were no postoperative complications. $\mathrm{X}$ rays revealed complete union of the fibular graft in the sinus tarsi.
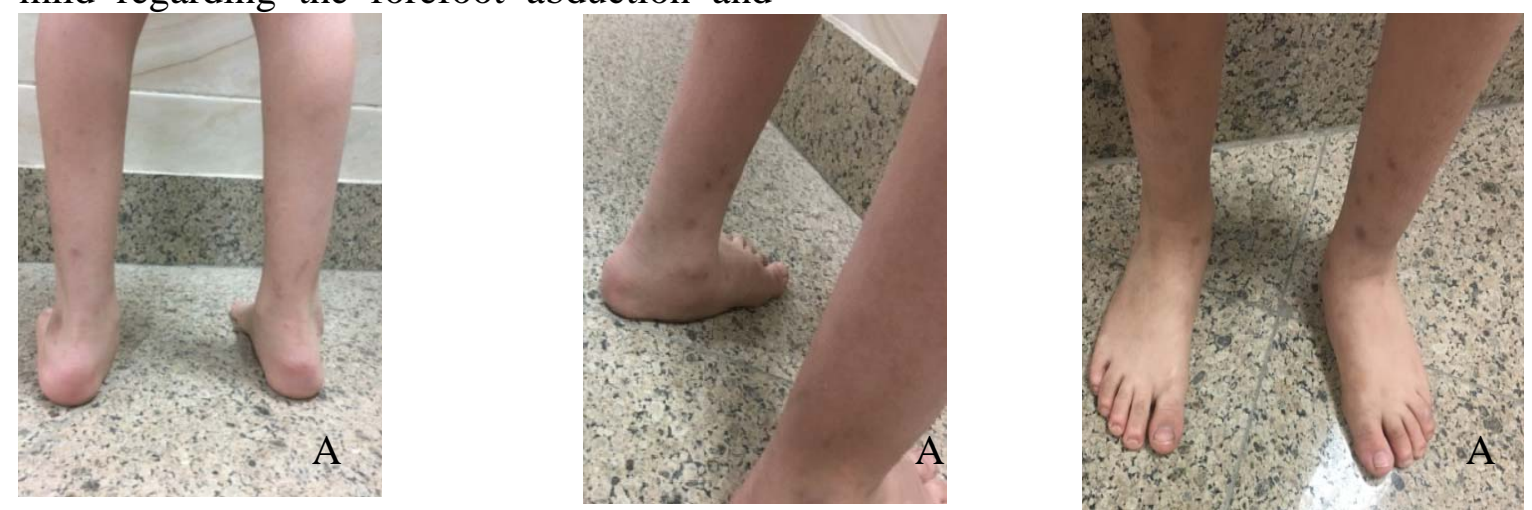


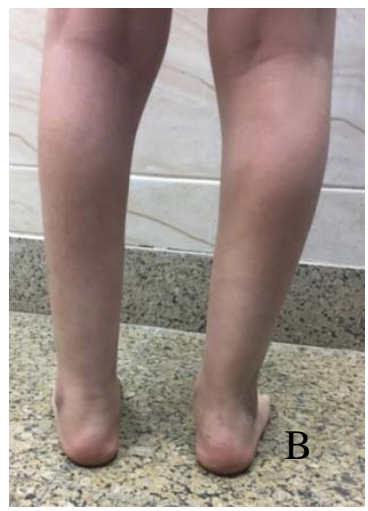

Fig 1: Clinical photos showing preop. (A) and postop. (B) Lt heel valgus.

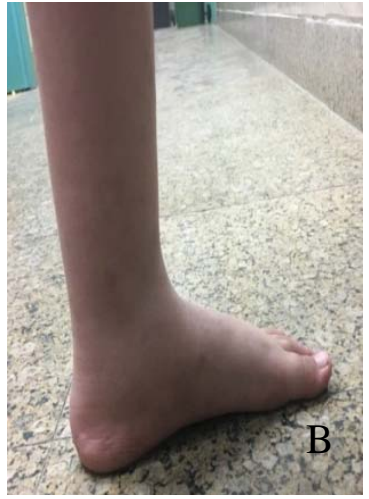

Fig. 2: Clinical photos showing preop. (A) and postop. (B) medial arch of the Lt foot.

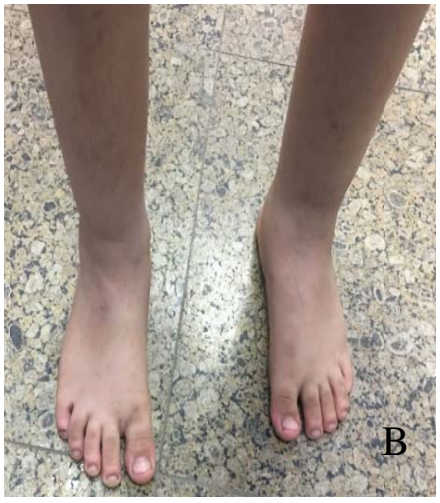

Fig. 3: Clinical photos showing preop. (A) and postop. (B) forefoot abduction

\section{Radiological outcome:}

Reduction of the Lat TCA (Fig. 4) from $48^{\circ}$ preoperative (A) to $34^{\circ}$ postoperative (B) indicates improvement of the hindfoot valgus. Reduction of the Lat. talo-1st MTS (Fig. 5) from $34^{\circ}$ preoperative (A) to $0^{\circ}$ postoperative
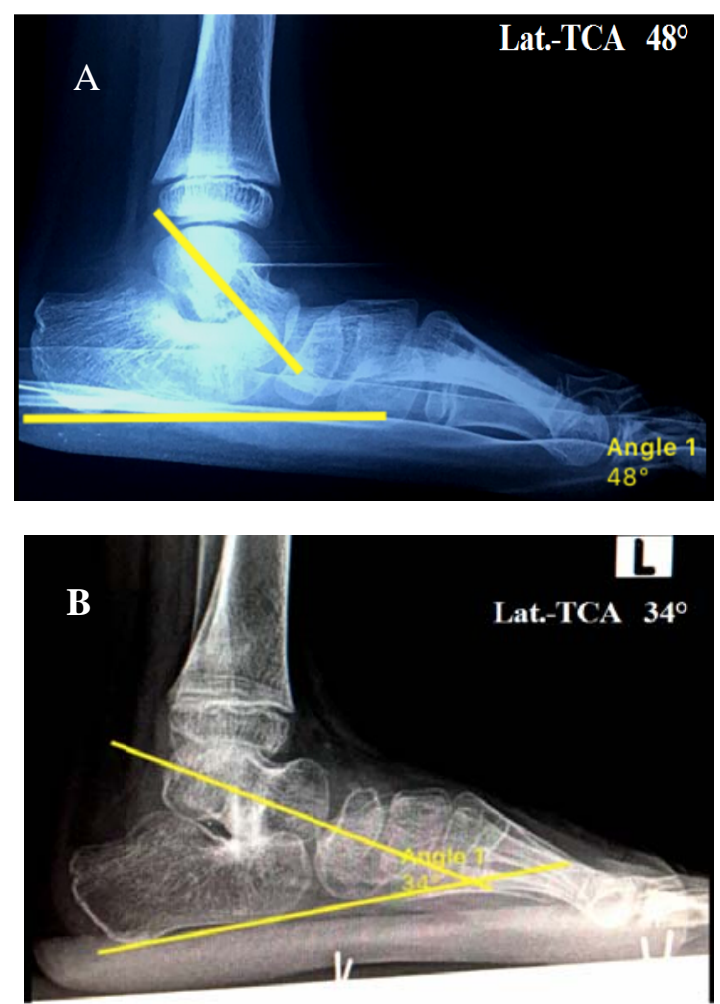

Fig. 4: Radiographs showing measurement of preop. (A) and postop. (B) lat.-TCA angles.
(B) indicates improvement of the foot medial longitudinal arch. Increase of the calcaneal pitch angle (Fig. 6) from $4^{\circ}$ preoperative (A) to $10^{\circ}$ postoperative (B) indicates improvement of the foot medial longitudinal arch.
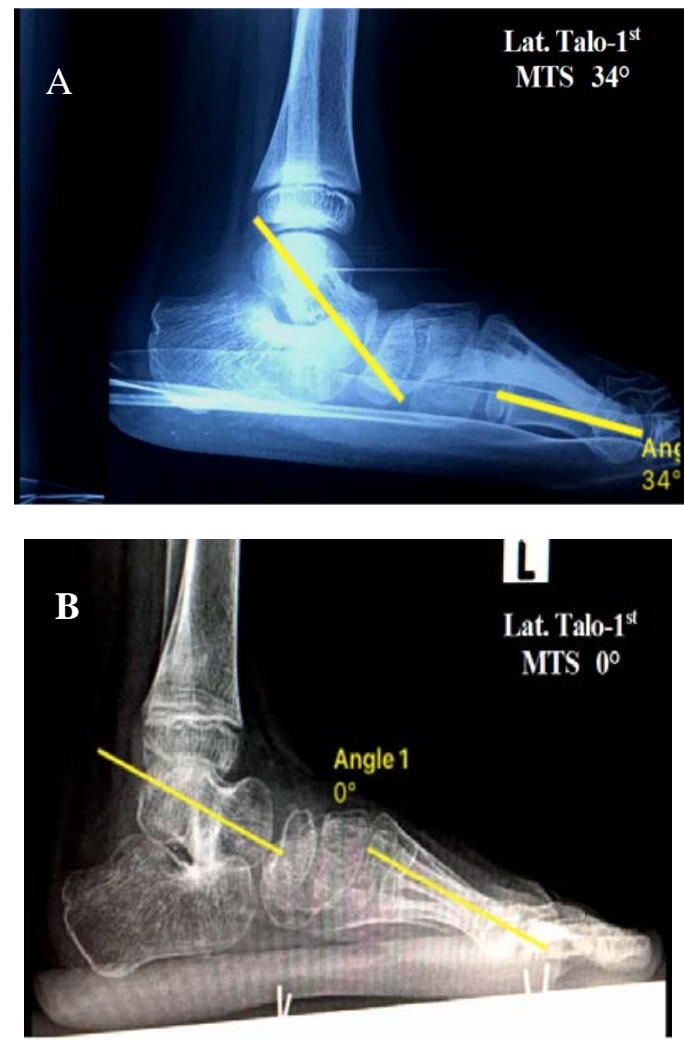

Fig. 5: Radiographs showing measurement of preop. (A) and postop. (B) lat. talo-1st MTS angles. 
Tarek Hassan Abdelaziz, et al.,
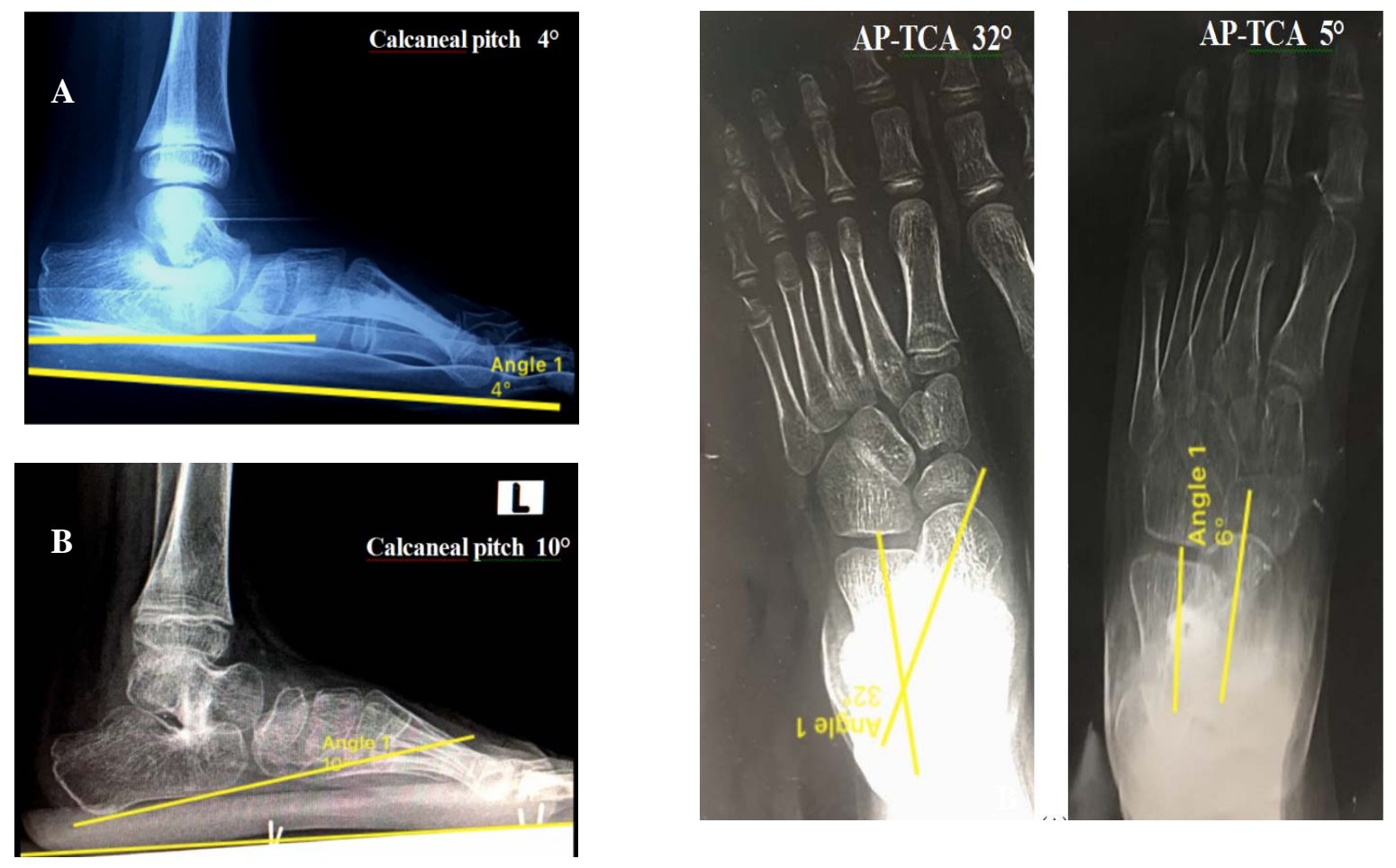

Fig. 7: Radiographs showing measurement of preop. (A) and postop. (B) AP-TCA

Fig. 6: Radiographs showing measurement of preop. (A) and postop. (B) calcaneal pitch angles. angles..

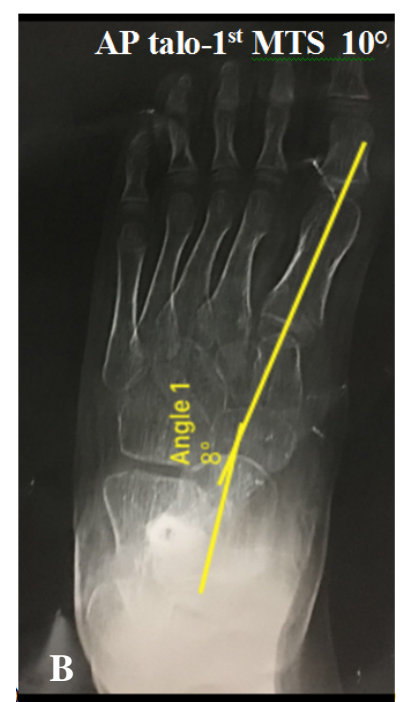

Fig. 8: Radiographs showing measurement of preop. (A) and postop. (B) AP talo 1st-MTS angles.

Reduction of the AP-TCA (Fig. 7) from $32^{\circ}$ preoperative (A) to $6^{\circ}$ postoperative (B) indicates improvement of the hindfoot valgus. Reduction of the AP talo-1st MTS
(Fig. 8) from $35^{\circ}$ preoperative (A) to $10^{\circ}$ postoperative (B) indicates improvement of the forefoot abduction. 
Table 4: Preoperative and postoperative radiographic measurements.

\begin{tabular}{|l|l|l|}
\hline & Pre & Post \\
\hline AP-TCA & 32 & 5 \\
\hline Lat. TCA & 48 & 34 \\
\hline AP talo-1st MTS & 35 & 10 \\
\hline Lat. Talo-1st MTS & 34 & 0 \\
\hline Calcaneal pitch angle & 4 & 10 \\
\hline
\end{tabular}

\section{DISCUSSION:}

Pes planovalgus is the most common foot deformity in all ages of children with cerebral palsy (CP), specifically among diplegic and quadriplegic patients. ${ }^{11,12}$

This deformity is initially flexible and can be treated with foot orthoses. While orthotics attempt to improve stability in stance and may protect foot joints from excessive loads. The evidence of these effects on a planovalgus foot in children with $\mathrm{CP}$ is lacking. The deformity often progresses because of increased body mass and foot load in ambulatory children or because of long-standing muscle imbalance in less ambulatory children. When surgical management is required, one needs to consider the three-dimensional complex nature of the deformity. The goal of treatment is to establish a plantigrade, stable foot by restoring a correct relationship between the tarsal bones and restoring more normal foot progression angle during gait. An effort should be made to preserve the flexibility and mobility of foot joints in an ambulatory child when possible, although keeping the midfoot stable is frequently an important goal as well. ${ }^{12}$

Extra-articular arthrodesis is a less invasive procedure than intra-articular fusion. Intra-articular subtalar and triple arthrodesis have been the most commonly used operations for severe forms of valgus hindfoot. Short-term follow up studies have shown reasonable results. However, surveys of longer duration showed that major complications and early degenerative changes in the peritalar joints occurred in between $23 \%$ and $54 \%$ of the cases. If possible, triple arthrodesis should be avoided in the growing period secondary to the transition of stress to still mobile joints. However, after Grice Green arthrodesis, degenerative joint disease was infrequently reported. This might be because of the reduction of hindfoot valgus deformity, which might prevent secondary arthritic changes. Furthermore, extra-articular intervention does not result in a full fusion of the subtalar joint facets. This is possibly the reason for a lower rate of degenerative changes in the adjacent joints when compared with intra-articular arthrodesis. ${ }^{13}$

High incidence of poor results owing to graft failures is a mis-interpretation of the outcome. Previous reports revealed that nonunion of the graft does not necessarily lead to recurrence of the deformity. Graft resorption neither influenced the outcome nor caused complications. The developing subtalar fibrosis is apparently solid in holding correction ${ }^{2,6,13}$. This is also proved in our study.

In comparison to the studies in the literature (table 4-5-6), our study gives accepted results and shows that the Grice Green is an effective method for correction of flexible PPV in CP either clinical or radiological.

In our study no child had a recurrence caused by residual forefoot supination. This might be due to the fact that we routinely used custom made orthosis (medial arch support) and custom made shoe (elevated medial border) in order to maintain the normal foot tripod structure supported. 
Table 5: Collective demographic data in the recent literature.

\begin{tabular}{|c|c|c|c|c|}
\hline Study & \begin{tabular}{ll|} 
No. of \\
patients
\end{tabular} & $\begin{array}{l}\text { Age at surgery } \\
\text { time }\end{array}$ & \begin{tabular}{|l|} 
Mean F/U \\
Range
\end{tabular} & Surgical technique \\
\hline $\begin{array}{l}\text { Bourelle et al. }{ }^{2} \\
2004\end{array}$ & $\begin{array}{l}26 \text { feet } \\
17 \text { ptn }\end{array}$ & \begin{tabular}{|l|}
5 yrs $5 \mathrm{~m}$ \\
$3 \mathrm{yrs} 10 \mathrm{~m}$ to $8 \mathrm{yrs}$ \\
$7 \mathrm{~m}$
\end{tabular} & $\begin{array}{l}20 \text { yrs, } 3 \mathrm{~m} 17 \text { yrs } 3 \\
\mathrm{~m} \text { to } 22 \text { yrs } 4 \mathrm{~m}\end{array}$ & $\begin{array}{l}\text { full segment of fibular graft from distal \& from } \\
\text { midthird }\end{array}$ \\
\hline $\begin{array}{l}\text { Guven et al. } \\
2008\end{array}$ & $\begin{array}{l}14 \text { feet } \\
9 \text { ptn }\end{array}$ & \begin{tabular}{|l|l|}
10.3 yrs \\
6 to 12 yrs
\end{tabular} & $\begin{array}{l}30 \mathrm{~m} \\
6 \text { to } 81 \mathrm{~m}\end{array}$ & $\begin{array}{l}\text { full thickness fibular graft that was obtained from } \\
\text { the distal } 1 / 3 \text { of the fibula above the syndesmosis } \\
\text { level }\end{array}$ \\
\hline $\begin{array}{l}\text { Yoon et al } \\
2010\end{array}$ & $\begin{array}{l}50 \text { feet } \\
30 \text { ptn }\end{array}$ & \begin{tabular}{|l|l}
9 yrs \\
5 to 18 yrs \\
\end{tabular} & \begin{tabular}{|l|l|}
$37 \mathrm{~m}$ \\
26 to $49 \mathrm{~m}$ \\
\end{tabular} & Iliac bone graft \& fixation with cannulated screw \\
\hline $\begin{array}{l}\text { Leidinger et al. } \\
{ }^{13} 2011\end{array}$ & $\begin{array}{l}57 \text { feet } \\
39 \text { ptn }\end{array}$ & \begin{tabular}{ll|}
$7.8 \pm 2.7 \quad 3.9$ & to \\
$14.4 \mathrm{yrs}$ &
\end{tabular} & $\begin{array}{l}22.6 \pm 4.616 \text { to } 32.3 \\
\text { yrs }\end{array}$ & $\begin{array}{l}\text { autologous tibia cortical graft from the medial } \\
\text { proximal tibia fixed with k-wire }\end{array}$ \\
\hline $\begin{array}{l}\text { Mazis et } \mathrm{al}^{14} \text {. } \\
2012\end{array}$ & $\begin{array}{l}16 \text { feet } \\
11 \text { ptn } \\
\end{array}$ & $\begin{array}{l}9 \text { yrs } 8 \mathrm{~m} 6 \text { yrs } 5 \\
\mathrm{~m} \text { to } 12 \text { yrs } 4 \mathrm{~m}\end{array}$ & $\begin{array}{l}3 \text { yrs } 7 \mathrm{~m} \text { (range, } 2 \\
\text { yrs } 1 \mathrm{~m} \text { to } 8 \text { yrs } 3 \mathrm{~m})\end{array}$ & $\begin{array}{l}\text { a full segment of fibular graft; between middle and } \\
\text { distal one-third }\end{array}$ \\
\hline $\begin{array}{l}\text { Bollmann et } \\
\mathrm{al}^{15} .2015\end{array}$ & $\begin{array}{l}127 \text { feet } \\
92 \mathrm{ptn}\end{array}$ & \begin{tabular}{|l|l|}
12.3 yrs \\
5 to 21 yrs \\
\end{tabular} & $\begin{array}{l}22.6 \mathrm{~m} \\
6 \text { to } 64 \mathrm{~m} \\
\end{array}$ & Full thickness fibular graft fixed with k-wire \\
\hline $\begin{array}{l}\text { Guven et } \mathrm{al}^{8} \text {. } \\
2016\end{array}$ & $\begin{array}{l}15 \text { feet } \\
11 \mathrm{ptn}\end{array}$ & $\begin{array}{l}10.7 \text { yrs } \\
6 \text { to } 15 \text { yrs }\end{array}$ & $\begin{array}{l}24 \mathrm{~m} \\
9 \text { to } 39 \mathrm{~m}\end{array}$ & $\begin{array}{l}\text { 2/3 semicircular partial fibular graft obtained from } \\
\text { the junction of the middle and distal third of the } \\
\text { fibula }\end{array}$ \\
\hline $\begin{array}{l}\text { Jagadesh G. et } \\
\mathrm{al}^{16} .2018,\end{array}$ & $\begin{array}{l}68 \text { feet } \\
40 \text { ptn }\end{array}$ & $\begin{array}{l}10 \text { yrs. (range } 6- \\
14 \text { yrs) }\end{array}$ & $\begin{array}{l}14 \mathrm{~m} \\
\text { (range } 4 \text { - } 24 \mathrm{~m} \text { ). }\end{array}$ & Batchelor's tecnique \\
\hline Our study & $\begin{array}{l}22 \text { feet } \\
13 \text { ptn }\end{array}$ & \begin{tabular}{|l|}
9 yrs \\
5.25 to 14 yrs
\end{tabular} & $\begin{array}{l}24 \mathrm{~m} \\
\text { (range 18-32m) }\end{array}$ & $\begin{array}{l}\text { Full thickness fibular graft from the junction } \\
\text { between proximal } 1 / 3 \text { and distal } 2 / 3 \text { fixed with k- } \\
\text { wire }\end{array}$ \\
\hline
\end{tabular}

Table 6: Collective radiological data in the recent literature.

\begin{tabular}{|c|c|c|c|c|c|c|c|c|c|c|}
\hline \multirow[t]{2}{*}{ Study } & \multicolumn{2}{|l|}{ AP taloMTS } & \multicolumn{2}{|l|}{ lat. Talo MTS } & \multicolumn{2}{|l|}{ AP- TCA } & \multicolumn{2}{|l|}{ Lat.-TCA } & \multicolumn{2}{|c|}{ Calc. pitch } \\
\hline & pre & post & pre & post & pre & post & pre & post & pre & post \\
\hline $\begin{array}{l}\text { Bourelle etal. } \\
2004\end{array}$ & & & & & 31 & 14 & 54 & 39 & & \\
\hline $\begin{array}{l}\text { Guven et al. } \\
2008\end{array}$ & & & & & 52.6 & 30.4 & 55.8 & 35.9 & & \\
\hline $\begin{array}{l}\text { Yoon et al., } \\
2010\end{array}$ & $26 \pm 11$ & $8 \pm 8$ & $23 \pm 11$ & $3 \pm 7$ & $30 \pm 7$ & $23 \pm 7$ & $35 \pm 11$ & $28 \pm 9$ & $8 \pm 6$ & $9 \pm 7$ \\
\hline $\begin{array}{l}\text { Leidinger } \\
\text { etal., } 2011\end{array}$ & & & & & & & $\begin{array}{l}53.9 \pm \\
8.9\end{array}$ & $37 \pm 8.2$ & $11.3 \pm 7.1$ & $17 \pm 7.3$ \\
\hline $\begin{array}{l}\text { Mazis etal., } \\
2012\end{array}$ & $22.7 \pm 10.95$ & $\begin{array}{l}8.1 \pm \\
5.07\end{array}$ & $22.4 \pm 7.4$ & $3.05 \pm 5.4$ & $21.9 \pm 7.2$ & $16.4 \pm 5.5$ & $\begin{array}{l}46 . \\
7 \pm 6.9\end{array}$ & $34.1 \pm 6.5$ & $8.95 \pm 3.86$ & $13.1 \pm 5.2$ \\
\hline $\begin{array}{l}\text { Bollmann } \\
\text { etal.,2015 }\end{array}$ & -28.48 & -2.64 & -39.98 & -12.32 & & & 49.52 & 31.49 & 2.95 & 7.55 \\
\hline $\begin{array}{l}\text { Güvena etal. } \\
2016\end{array}$ & $22.1 \pm 9.4$ & $6.5 \pm 2$ & $18.2 \pm 11.6$ & $6.4 \pm 3.5$ & $41.3 \pm 8.5$ & $25.7 \pm 2.6$ & $44-7.3$ & $28.6 \pm 3$ & $10.4 \pm 3.9$ & $16.9 \pm 2.7$ \\
\hline $\begin{array}{l}\text { Jagadesh G. } \\
\text { et al. 2018, }\end{array}$ & & & & & & & $\begin{array}{l}44(32 \\
\text { to } 56)\end{array}$ & $\begin{array}{l}30 \text { (20 to } \\
44)\end{array}$ & & \\
\hline Our study & $\begin{array}{l}24 \text { (range } 3 \\
-55 \text { ) }\end{array}$ & $\begin{array}{l}8 \text { (range } \\
1-39)\end{array}$ & $\begin{array}{l}20 \text { (range } 3 \\
-47 \text { ) }\end{array}$ & $\begin{array}{l}8.5 \text { (range } \\
0-18)\end{array}$ & $\begin{array}{l}26 \quad \text { (range } \\
11-56)\end{array}$ & $\begin{array}{l}9.5 \text { (range } \\
1-35)\end{array}$ & $\begin{array}{l}42.05 \pm \\
7.35\end{array}$ & $\begin{array}{l}28.73 \pm \\
8.51 \\
\end{array}$ & $\begin{array}{l}5 \text { (range }-19 \\
-22 \text { ) }\end{array}$ & $\begin{array}{l}10 \text { (range } \\
2-17)\end{array}$ \\
\hline
\end{tabular}


Correction Of Pes Planovalgus In Cerebral Palsy: A Short Term Outcome Of Extra-Articular..

Table 7: Collective clinical data in the recent literature.

\begin{tabular}{|c|c|c|c|}
\hline Study & satisfactory & unsatisfactory & Comments \\
\hline Bourelle etal. 2004 & $\begin{array}{l}20 \text { of } 26 \text { feet satisfied. } \\
19 \text { normal footprint, } 6 \text { type } \\
2 \text { flatfoot, one } 3^{\text {rd }} \text { degree } \\
\text { cavus }\end{array}$ & & 6 feet expressed no opinion \\
\hline Guven etal. 2008 & $\begin{array}{l}\text { AOFAS hindfoot score } \\
\text { increased from } 53 \text { (range } \\
41 \text { to } 81 \text { ) to } 68.4 \text { (range } 51 \\
\text { to } 96 \text { ) }\end{array}$ & & \\
\hline Yoon et al., 2010 & $\begin{array}{lcr}\text { Improvement } & \text { of } & \text { foot } \\
\text { deformities } & \text { on } & \text { high } \\
\text { resolution } & \text { pressure } \\
\text { assessment system } & \end{array}$ & & $\begin{array}{l}\text { All ptn showed more upright } \\
\text { posture and increased knee } \\
\text { extension during stance after } \\
\text { surgery. }\end{array}$ \\
\hline Leidinger etal., 2011 & $\begin{array}{l}\text { Of } 51 \text { feet; } 39 \text { excellent } \\
8 \text { fair }\end{array}$ & 4 poor & Overcorrection \\
\hline Mazis etal., 2012 & & & $\begin{array}{l}\text { Depended on } \\
\text { evaluation }\end{array}$ \\
\hline Bollmann etal.,2015 & $\begin{array}{l}\text { Of } 127 \text { feet; } \\
116 \text { satisfied }\end{array}$ & $\begin{array}{l}8 \text { undercorrected } \\
3 \text { overcorrected }\end{array}$ & \\
\hline Guven etal. 2016 & 10 of 11 ptn (13 feet) & 1 ptn (2 feet) & \begin{tabular}{lrr}
\multicolumn{3}{l}{ Quadriplegic } \\
Parents not & satisfied, & although \\
clinical & appearance & and \\
radiographic & results & were \\
satisfactory. & & \\
\end{tabular} \\
\hline $\begin{array}{l}\text { Jagadesh G. et al. } \\
2018,\end{array}$ & 44 feet & 24 feet & $\begin{array}{lll}\begin{array}{l}\text { AOFAS } \\
\text { improved }\end{array} & \text { score } & \text { significantly } \\
\end{array}$ \\
\hline Our study & 21 of 22 satisfied & 1 unsatisfied & Undercorrected \\
\hline
\end{tabular}

\section{Conclusion:}

In conclusion, extra-articular subtalar arthrodesis is a powerful, simple, non-expensive and safe procedure in $\mathrm{CP}$ patients when addressing symptomatic flexible pes planovalgus deformities that failed conservative treatment.It does not cause degenerative joint disease and allow preservation of the foot growth. Resorption of the bone graft does not influence the results.

The procedure offers early and long-lasting correction. It helps to improve a patient's ambulatory duration and to simplify the use orthotic devices. Taking the fibular graft as high as the junction between proximal $1 / 3$ and distal $2 / 3$ with caution to the nerve as this can reduce the risk of postoperative ankle valgus. Postoperative use of custom made orthopedic shoe with elevated medial border and medial arch support as this can minimize the risk of recurrence as this maintained tripod structure of the foot supported.

\section{REFERENCES}

1. Yoon H.K. et al., Extraarticular Subtalar Arthrodesis for Pes Planovalgus: An Interim Result of 50 Feet in Patients with Spastic Diplegia. Clinics in Orthopedic Surgery 2010;2:13-21.

2. Bourelle S. et al. Extra-articular subtalar arthrodesis. The Journal of Bone and Joint Surgery. British volume. 2004;86-B:737-42.

3. Andreacchio A. et al. Lateral column lengthening as treatment for palnovalgus foot deformity in ambulatory children with spastic cerebral palsy. J PediatrOrthop, 2000.20:501-505.

4. Yoo WJ. et al. Calcaneal lengthening for the planovalgus foot deformity in children with cerebral palsy. J PediatrOrthop, 2005, 25:781-785.

5. Kim J.R. et al. Comparison of Lateral Opening Wedge Calcaneal Osteotomy and Medial Calcaneal Sliding-opening Wedge 


\section{Tarek Hassan Abdelaziz, et al.,}

Cuboid-closing Wedge Cuneiform Osteotomy for Correction of Planovalgus Foot Deformity in Children. The Journal of Foot\& Ankle Surgery. 2013, 52:162-166.

6. Guven M. et al. The results of the Grice subtalar extra-articular arthrodesis for pes planovalgus deformity in patients with cerebral palsy. acta orthopaedica et traumatologica turcica. 2008;42:31-7.

7. Harris EJ, Vanore JV etal., Diagnosis and Treatment of Pediatric Flatfoot. The journal of foot and ankle surgery, Vol. 43, No. 6, Nov./Dec. 2004.

8. Guven M. et al. Modified Grice-Green subtalar arthrodesis performed using a partial fibular graft yields satisfactory results in patients with cerebral palsy. Journal of Pediatric Orthopaedics $B$. 2016;25:119-25

9. Malhotra D, Puri $R$, Owen $R$. Valgus deformity of the ankle in children with spina bifida aperta.J Bone Joint Surg Br1984;66:381-385.

10. Dogan A. et al. A comparison of two different techniques in the surgical treatment of flexible pes planovalgus: calcaneal lengthening and extra-articular subtalar arthrodesis. Journal of Pediatric Orthopaedics B 2009, Vol 18 No 4.
11. Kadhim M. et al. Pes planovalgus deformity surgical correction in ambulatory children with cerebral palsy. Journal of Children Orthopaedics. 2012;6:217-27.

12. Kedem P, Scher DM. Foot deformities in children with cerebral palsy. Current Opinion in Pediatrics. 2015;27:67-74.

13. Leidinger B. et al. Grice-Green Procedure for Severe Hindfoot Valgus in Ambulatory Patients with Cerebral Palsy. The Journal of Foot and Ankle Surgery. 2011;50:190-6.

14. Mazis GA et al. Results of Extra-Articular Subtalar Arthrodesis in Children with Cerebral Palsy. Foot \& Ankle International. 2012;33:469-74.

15. Bollmann C, Franz A, Raabe J. Die extraartikuläre Arthrodese nach Grice und Green mit Implantation eines Fibulaspans Nachuntersuchung von 92 Patienten. Zeitschrift für Orthopädie und Unfallchirurgie. 2015;153:93-8.

16. Jagadesh GM. et al. Outcome of surgical management of plano-valgus foot in cerebral palsy with batchelor's extra-articular subtalar arthrodesis. Indian Journal of Orthopaedics Surgery. 2018;4:60-4. 


\section{اصلاح القدم المفلطحة فى مرضى الثلل الدماغى :النتائج قصيرة المدى لتثبيث خارج مفصل تحت الثالوث.}

\section{طارق حسن عبد العزيز ومحمد نبيل السيد و عمرو فاروق وأحمد سعيد ومحمد نبيل محمود عطية}

قسم جراحة العظام، كلية الطب، جامعة عين شمس

المقدمة: تعد القدم المفلطحة الرحاء أكثر تشوهات القدم شيوعا فى الأطفال المصابين بالثلل الدماغى والتى تسبب ألم، صعوبة

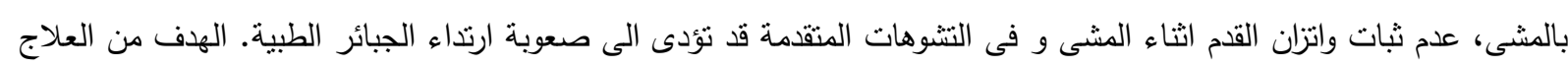

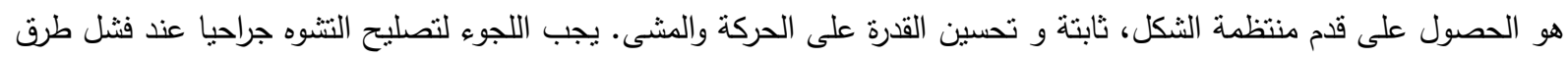

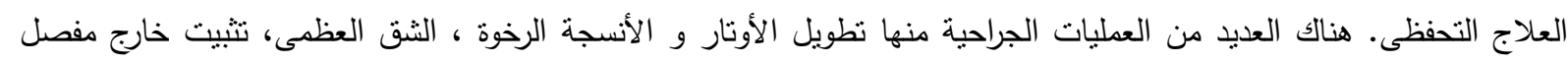

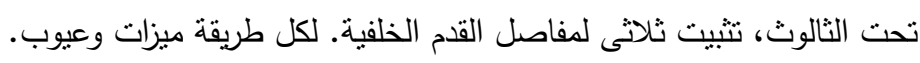

اللهيف من الدراسة: نقييم النتائج قصيرة المدى لجراحة تثبيت خارج مفصل تحت الثالوث باستخدام ترقيع عظمى من عظمة

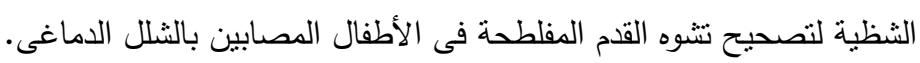
الحالات و طق البحث: كان عدد الدراسة لدينا r ق قدما (rا مريض) كلهم مصابين بالثلل الدماغى. كانت معايير الإثتمال

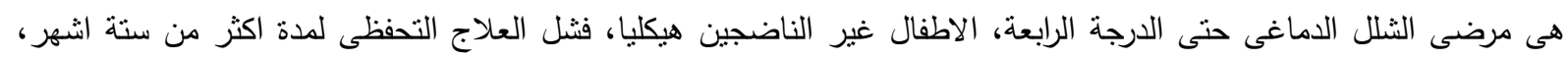

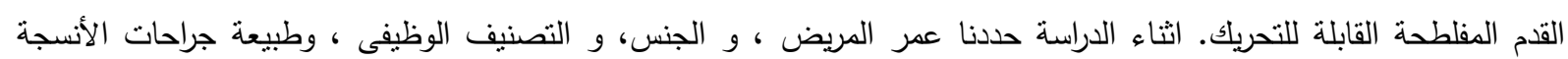
الرخوة.تم تقييم المرضى اكلينيكيا و عن طريق قياس الزوايا الضرورية على الأشعة العادية.

النتائج: نم تقييم تحسن المرضى اكلينيكيا عن طريق تقييم تحسن درجة تشوه القدم الأمامية الخارجى ،و تشوه القدم الخلفية

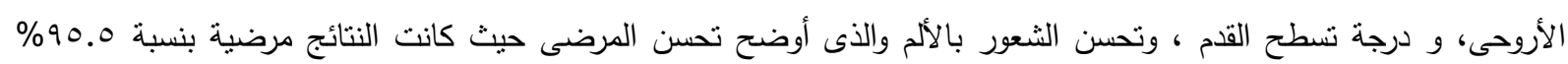

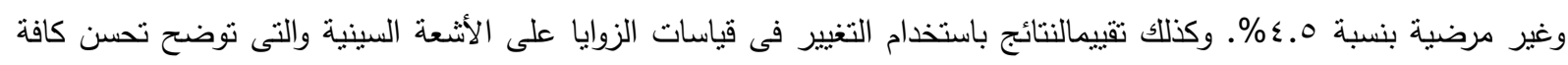
الزوايا بنسب ذات دلالة احصائية ايجابية.

خلاصة البحث: بدراسة النتائج فإن تثبيت خارج مفصل تحت الثالوث نجح فى تصحيح نثوه القدم الدفلطحة بدرجة كبيرة فى

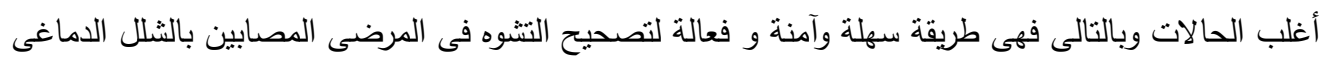

